\title{
Interdependence of productive properties of Holstein breed cows on biomass and use of mobile milking machines
}

\author{
$M$. Ashirov ${ }^{1, *}, D$. Omonov $^{2}, R$. Khalilov $^{2}$, and $U$. Rakhimov ${ }^{3}$ \\ ${ }^{1}$ Scientific Research Institute of Animal Sciences, Poultry and Fishery, Kizil Shalola hamlet, \\ Tashkent, Uzbekistan, 111121 \\ ${ }^{2}$ Tashkent State Agrarian University, University str., 2, Tashkent province, Uzbekistan, 100140 \\ ${ }^{3}$ Samarkand Institute of Veterinary Medicine, Mirzo Ulugbek str., Samarkand, Uzbekistan
}

\begin{abstract}
Studies have established that the highest monthly milk yield in cows of all groups was noted in the third month of lactation. In this month of lactation in cows of the III group with a live weight of $481 \mathrm{~kg}$ and more, the monthly milk yield was, respectively, 44 and $24 \mathrm{~kg}$ higher than in the peers of the I and II groups. The highest monthly milk yield of cows of groups I, II and III was, respectively, $12.33 \%, 12.37 \%$ and $12.53 \%$ of milk yield per lactation. Studies have confirmed that the level of payment for feed with dairy products is closely related to the level of milk production of cows. The cost of feed units for milk production in high-yielding cows is noticeably lower than in less productive peers. It was also found that the use of mobile mobile milking machines contributes to the complete milking and the manifestation of the potential of milk productivity of Holstein cows.
\end{abstract}

\section{Introduction}

In the context of increasing the production of livestock products, it is important to use the potential of the leading breeds of the world gene pool and identify opportunities for improving productivity, taking into account various factors [1-3]. Among the breeds of dairy cattle in the world, the Holstein breed is recognized as the leader [4]. The cattle of this breed are distinguished by extremely high milk productivity and suitability for use in modern high-performance milking installations, with good adaptability to various soil and climatic conditions and other valuable qualities $[4,5]$. Due to these valuable properties, Holstein cattle are widely used in many countries of almost all continents of the world [6].

The level of milk production of cows depends both on the genotype and on numerous environmental factors or paratypical factors [7]. Body weight, in particular at first calving, also has a significant impact on the level of milk production of cows [7-9]. In this regard, the identification of the relationship of live weight at the first calving with further milk productivity is important for the further effective use of the potential of cows and is relevant [10].

\footnotetext{
*Corresponding author: m.a.ashirov@yandex.com
} 


\section{Materials and methods}

The research was carried out in the breeding herd of the K. Eldor farm in the Pastdargom district of the Samarkand region of Uzbekistan on Holstein cows of I, II lactation. For the experiment, according to the principle of analogs, three groups of firstcalf heifers of the Holstein breed, 15 heads each, were selected. Group I included cows with an average live weight at the first calving up to $460 \mathrm{~kg}$, in II $-461-480 \mathrm{~kg}$, in III - $481 \mathrm{~kg}$ and more. The cows were fed with the same type of feeding, taking into account the level of milk production, live weight and physiological state. The productive indicators of cows have been studied by methods generally accepted in animal husbandry.

The research used a mobile mobile milking machine manufactured by Asimilk brand YDH-002, which is designed for milking cows on small dairy farms. It is designed in accordance with the International Standard [11], allowing to milk 20-24 cows per hour.

The working vacuum is $0.04 \mathrm{MHz}$, the pulsation is 0.4 times per minute, the motor power is $0.55 \mathrm{~kW}$, the voltage stabilizer is $220 \mathrm{~V}$. The engine rotation speed is $1450 \mathrm{rpm}$, the number of milk collection tanks is 2, 25 liters each, number of teat cups - 4 . The device provides complete milking of the cow. The use of this mobile milking machine provided a milk flow rate of $1.26-1.48 \mathrm{~kg} / \mathrm{min}$ for first-calf cows.

\section{Results and discussion}

Studies have shown that the level of milk production of cows depends on the live weight at the first calving (Table 1).

Table 1. Milk productivity of cows for I lactation

\begin{tabular}{|c|c|c|c|c|c|c|}
\hline \multirow{3}{*}{ Indicator } & \multicolumn{6}{|c|}{ Group } \\
\cline { 2 - 7 } & \multicolumn{2}{|c|}{$\mathbf{I}$} & \multicolumn{2}{c|}{ II } & \multicolumn{2}{c|}{ III } \\
\cline { 2 - 7 } & $\bar{X}_{ \pm \mathbf{S}} \overline{\bar{x}}$ & $\mathbf{C}_{\mathbf{v}}, \%$ & $\bar{X}_{ \pm \mathbf{S}} \bar{x}$ & $\mathbf{C}_{\mathbf{v}}, \%$ & $\bar{X}_{ \pm \mathbf{S}} \overline{\bar{x}}$ & $\mathbf{C}_{\mathbf{v}}, \mathbf{\%}$ \\
\hline Milk yield, kg & $4283.6 \pm 72.0$ & 6.29 & $4430.7 \pm 75.3$ & 6.36 & $4565.6 \pm 107.1$ & 8.78 \\
\hline Milk fat, \% & $3.94 \pm 0.035$ & 3.29 & $3.93 \pm 0.026$ & 2.44 & $3.91 \pm 0.03$ & 2.67 \\
\hline $\begin{array}{c}\text { Milk fat yield, } \\
\text { kg }\end{array}$ & $168.7 \pm 2.03$ & 4.52 & $174.1 \pm 2.17$ & 4.68 & $178.5 \pm 3.11$ & 6.52 \\
\hline 4\% milk, kg & $4219.3 \pm 49.5$ & 4.40 & $4353.2 \pm 54.5$ & 4.69 & $4462.9 \pm 77.7$ & 6.53 \\
\hline Biomass, kg & $450.3 \pm 4.69$ & 3.90 & $470.1 \pm 1.82$ & 5.47 & $489.7 \pm 2.25$ & 1.72 \\
\hline
\end{tabular}

Studies have shown that the milk yield of first-calf cows of the III group exceeds, respectively, by $282.0 \mathrm{~kg}(\mathrm{P}>0.95)$ and $134.9 \mathrm{~kg}(\mathrm{P}>0.999)$, the yield of milk fat by 10.8 and $4.4 \mathrm{~kg}(\mathrm{P}>0.99)$, milk yield of $4 \%$ milk by $243.6(\mathrm{P}>0.99)$ and $209.7(\mathrm{P}>0.95) \mathrm{kg}$ indicators of contemporaries of groups I and II. Studied milk productivity of cows of these groups and for II lactation were demonstrated below (Table 2). 
Table 2. Performance indicators of cows for II lactation

\begin{tabular}{|c|c|c|c|c|c|c|}
\hline \multirow{3}{*}{ Indicator } & \multicolumn{6}{|c|}{ Group } \\
\cline { 2 - 7 } & \multicolumn{2}{|c|}{$\mathbf{I}$} & \multicolumn{2}{c|}{ II } & \multicolumn{2}{c|}{ III } \\
\cline { 2 - 7 } & $\bar{X}_{ \pm \mathbf{S}} \bar{x}$ & $\mathbf{C}_{\mathbf{v}}, \%$ & $\bar{X}_{ \pm \mathbf{S}} \overline{\bar{x}}$ & $\mathbf{C}_{\mathbf{v}}, \%$ & $\bar{X}_{ \pm \mathbf{S}} \overline{\bar{x}}$ & $\mathbf{C}_{\mathbf{v}}, \%$ \\
\hline $\begin{array}{c}\text { Milk yield, } \\
\text { kg }\end{array}$ & $4740.2 \pm 92.6$ & 7.31 & $4949.0 \pm 104.6$ & 7.91 & $5205.5 \pm 113.5$ & 8.16 \\
\hline Milk fat, \% & $3.91 \pm 0.03$ & 2.54 & $3.89 \pm 0.03$ & 2.75 & $3.86 \pm 0.04$ & 3.61 \\
\hline $\begin{array}{c}\text { Milk fat } \\
\text { yield, kg }\end{array}$ & $185.3 \pm 2.8$ & 5.58 & $192.5 \pm 2.95$ & 5.73 & $200.9 \pm 3.43$ & 6.44 \\
\hline $4 \%$ milk, kg & $4633.5 \pm 65.6$ & 5.30 & $4812.9 \pm 74.9$ & 5.83 & $5022.8 \pm 86.5$ & 6.50 \\
\hline Biomass, kg & $497.1 \pm 5.48$ & 4.13 & $523.3 \pm 6.74$ & 4.82 & $552.4 \pm 6.70$ & 4.54 \\
\hline
\end{tabular}

As evidenced by the data in Table 2, the milk yield of cows of group III for lactation II exceeds the milk yield of peers of groups I and II, respectively by $465.3 \mathrm{~kg}(\mathrm{P}>0.99)$ and $256.5 \mathrm{~kg}$, milk fat yield by $15.6 \mathrm{~kg}(\mathrm{P}>0.999)$ and $8.4 \mathrm{~kg}$, milk yield of $4 \%$ milk per 389,3 and $209.9 \mathrm{~kg}$. In lactation II, the milk yield of cows of group I in comparison with lactation I increases by $456.6 \mathrm{~kg}(\mathrm{P}>0.999)$, in group II by $518.3 \mathrm{~kg}(\mathrm{P}>0.999)$ and in group III by $639.9 \mathrm{~kg}(\mathrm{P}>0.999)$ milk, while other studied parameters of productivity increase noticeably. Studied the yield of dairy products of cows for I lactation were shown in Table 3 .

Table 3. The yield of dairy products for every $100 \mathrm{~kg}$ of live weight in cows for the 1 st lactation

\begin{tabular}{|c|c|c|c|}
\hline \multirow{2}{*}{ Indicator } & \multicolumn{3}{|c|}{ Group } \\
\cline { 2 - 4 } & I & II & III \\
\hline Biomass, kg & 445.7 & 462.2 & 473.7 \\
\hline $\begin{array}{c}\text { Milk production per 100 kg } \\
\text { of biomass, kg }\end{array}$ & 951.3 & 942.5 & 932.3 \\
\hline $\begin{array}{c}\text { Produced for every 100 kg } \\
\text { of biomass: }\end{array}$ & 937.0 & 926.0 & 911.3 \\
\hline $4 \%$ milk, kg & 37.46 & 37.03 & 37.45 \\
\hline milk fat, kg & \multicolumn{3}{|l}{} \\
\hline
\end{tabular}

As the data in Table 3 show, in cows of group I, milk production per $100 \mathrm{~kg}$ of live weight was respectively 8.8 and $1.9 \mathrm{~kg}$ higher, milk yield of $4 \%$ milk was 11.0 and $25.7 \mathrm{~kg}$ higher than that of contemporaries of groups II and III, with practically equal yield of milk fat.

The research studied the level of payment for feed with dairy products in first-calf heifers (Table 4).

Table 4. Payment for feed with dairy products

\begin{tabular}{|c|c|c|c|}
\hline \multirow{2}{*}{ Indicator } & \multicolumn{3}{|c|}{ Group } \\
\cline { 2 - 4 } & I & II & III \\
\hline $\begin{array}{c}\text { Fodder units consumed on } \\
\text { average per 1 heifer, kg }\end{array}$ & 4584.4 & 4652.2 & 4702.6 \\
\hline Milk yield, kg & 4283.6 & 4430.7 & 4565.6 \\
\hline $4 \%$ milk, kg & 4219.3 & 4353.2 & 4462.9 \\
\hline $\begin{array}{c}\text { Cost of feed units for the } \\
\text { production of 1 kg of natural } \\
\text { milk, kg }\end{array}$ & 1.07 & 1.05 & 1.03 \\
\hline \begin{tabular}{c} 
Cost of feed units for the \\
\hline
\end{tabular} & 1.09 & 1.07 & 1.05 \\
\hline
\end{tabular}




\begin{tabular}{|c|c|c|c|}
\hline $\begin{array}{c}\text { production of } 1 \mathrm{~kg} \text { of } 4 \% \text { milk, } \\
\mathrm{kg}\end{array}$ & & & \\
\hline $\begin{array}{c}\text { Produced for every } 100 \mathrm{~kg}: \\
\text { natural milk, kg }\end{array}$ & 93.44 & 93.57 & 97.09 \\
\hline $4 \%$ milk, kg & 92.04 & 93.57 & 94.90 \\
\hline
\end{tabular}

Studies have confirmed that the level of payment for feed with milk is closely related to the level of milk production. In cows of the III group with a higher milk yield, the cost of feed units for the production of $1 \mathrm{~kg}$ of natural milk is respectively 3.8 and $2.0 \%$, for the production of $1 \mathrm{~kg}$ of $4 \%$ milk by 3.7 and $1.9 \%$ less than for their peers Groups I and II, however, for every 100 feed units, the production of natural milk in the III group by $3.65 \mathrm{~kg}$ $(3.91 \%)$ and $3.52 \mathrm{~kg}(3.76 \%)$, the production of $4 \%$ milk by $2.86 \mathrm{~kg}(3.11 \%)$ and $1.33 \mathrm{~kg}$ $(1.42 \%)$ more than among the peers of the above groups.

Moreover, during this research, the nature of the course of lactation of cows in experimental groups for I lactation were studied (Table 5).

Table 5. Nature of the lactation course of cows in the experimental groups for the 1st lactation

\begin{tabular}{|c|c|c|c|c|c|c|c|c|c|}
\hline \multirow[b]{3}{*}{ 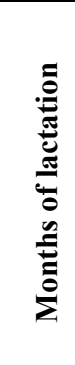 } & \multicolumn{9}{|c|}{ Group } \\
\hline & \multicolumn{3}{|c|}{ I } & \multicolumn{3}{|c|}{ II } & \multicolumn{3}{|c|}{ III } \\
\hline & 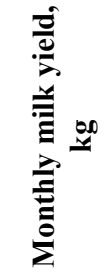 & 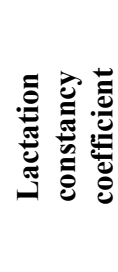 & 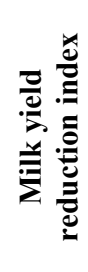 & 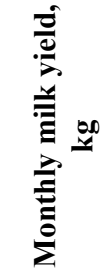 & 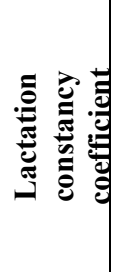 & 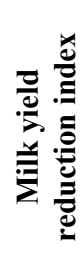 & 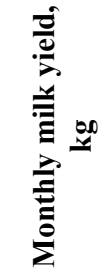 & 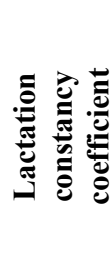 & 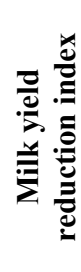 \\
\hline I & 324 & 100.0 & 61.4 & 341.6 & 100.0 & 62.3 & 376 & 100.0 & 65.7 \\
\hline II & 475.5 & 146.7 & 90.0 & 492 & 144.0 & 89.8 & 515 & 136.9 & 90.0 \\
\hline II & 528 & 121.9 & - & 548 & 111.4 & - & 572 & 111.1 & - \\
\hline IV & 506 & 95.8 & 95.8 & 536.5 & 97.9 & 97.9 & 550.4 & 96.2 & 96.2 \\
\hline $\mathrm{V}$ & 493.4 & 97.5 & 93.4 & 511 & 95.2 & 93.2 & 525.8 & 95.5 & 91.9 \\
\hline VI & 470.7 & 95.4 & 89.1 & 480 & 93.9 & 87.6 & 486.5 & 92.5 & 85.0 \\
\hline VII & 440.6 & 93.6 & 83.4 & 452.4 & 94.2 & 82.5 & 462.6 & 95.1 & 80.9 \\
\hline VII & 422.3 & 95.8 & 75.0 & 423.2 & 93.5 & 77.2 & 430 & 92.9 & 75.2 \\
\hline IX & 392.5 & - & 74.3 & 396.0 & - & 72.3 & 382.3 & - & 66.8 \\
\hline $\mathrm{X}$ & 230.6 & - & 43.7 & 250 & - & 45.6 & 265 & - & 46.3 \\
\hline Avg. & $4,283.6$ & 105.8 & - & $4,430.7$ & 103.8 & - & $4,565.6$ & 102.5 & - \\
\hline
\end{tabular}

The data in Table 4 indicate that the highest monthly milk yield in all groups was noted in the third month of lactation, at which the monthly milk yield in cows of the III group exceeds the indicators of the peers of I and II groups, respectively, by 44 and $24 \mathrm{~kg}$. At the same time, the monthly milk yield of cows in group I was $12.33 \%$, in group II $-12.37 \%$, in group III $-12.53 \%$ of the milk yield for I lactation.

The study of the coefficient of constancy of lactation shows that the monthly milk yield of cows is kept at a sufficiently high level until the sixth month of lactation, then a gradual decrease is noted. The uniform flow of lactation of cows is also evidenced by the index of milk yield decrease, which in the experimental groups from the third to the tenth month in groups I, II and III was 43.7, respectively; 45.6 and 46.3. The nature of the course of lactation and cows II lactation were also studied (Table 6). 
Table 6. Indicators of the nature of the course of lactation in cows for II lactation

\begin{tabular}{|c|c|c|c|c|c|c|c|c|c|}
\hline \multirow[b]{3}{*}{ 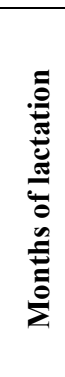 } & \multicolumn{9}{|c|}{ Group } \\
\hline & \multicolumn{3}{|c|}{ I } & \multicolumn{3}{|c|}{ II } & \multicolumn{3}{|c|}{ III } \\
\hline & 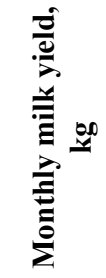 & 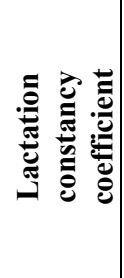 & 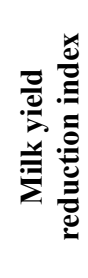 & 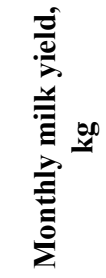 & 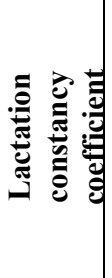 & 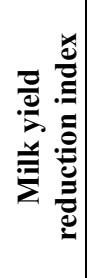 & 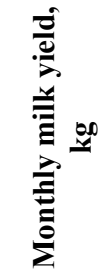 & 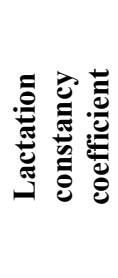 & 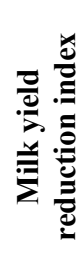 \\
\hline I & 324 & 100.0 & 61.4 & 341.6 & 100.0 & 62.3 & 376 & 100.0 & 65.7 \\
\hline II & 475.5 & 146.7 & 90.0 & 492 & 144.0 & 89.8 & 515 & 136.9 & 90.0 \\
\hline II & 528 & 121.9 & - & 548 & 111.4 & - & 572 & 111.1 & - \\
\hline IV & 506 & 95.8 & 95.8 & 536.5 & 97.9 & 97.9 & 550.4 & 96.2 & 96.2 \\
\hline V & 493.4 & 97.5 & 93.4 & 511 & 95.2 & 93.2 & 525.8 & 95.5 & 91.9 \\
\hline VI & 470.7 & 95.4 & 89.1 & 480 & 93.9 & 87.6 & 486.5 & 92.5 & 85.0 \\
\hline VII & 440.6 & 93.6 & 83.4 & 452.4 & 94.2 & 82.5 & 462.6 & 95.1 & 80.9 \\
\hline VII & 422.3 & 95.8 & 75.0 & 423.2 & 93.5 & 77.2 & 430 & 92.9 & 75.2 \\
\hline IX & 392.5 & - & 74.3 & 396.0 & - & 72.3 & 382.3 & - & 66.8 \\
\hline$X$ & 230.6 & - & 43.7 & 250 & - & 45.6 & 265 & - & 46.3 \\
\hline Avg. & $4,283.6$ & 105.8 & - & $4,430.7$ & 103.8 & - & $4,565.6$ & 102.5 & - \\
\hline
\end{tabular}

In the II lactation of cows of I and III groups, the highest monthly milk yield was reached in the third month of lactation, the II group in the third month. The highest monthly milk yields of cows in groups I, II and III were 15.1, respectively; 14.9 and $14.8 \%$ of milk yield per lactation. Studies have shown that cows of all groups have a high level of monthly milk yield up to the sixth month of lactation, as evidenced by the coefficient of constancy of lactation.

The uniform course of lactation of cows is also shown by the index of decrease in milk yield of cows, which from the highest monthly milk yield is marked by its gradual decrease towards the end of lactation. These results indicate that, regardless of the live weight at the first calving, lactation in cows proceeds evenly.

\section{Conclusion}

Milk productivity of Holstein cows depends on the live weight at the first calving. In cows of the III group, the milk yield for lactation I exceeds the milk yield of the peers of the I and II groups, respectively, by 282.0 and $134.9 \mathrm{~kg}$, the yield of milk fat by 10.8 and $4.4 \mathrm{~kg}$, for II lactation these indicators are higher by 465,3 and $256.5 \mathrm{~kg}$, the yield of milk fat by 15.6 and $8.4 \mathrm{~kg}$ than in cows of the studied experimental groups, in II lactation compared with I lactation significantly increase, respectively, by $456.6 ; 518.3$ and $639.9 \mathrm{~kg}$ of milk, by $16.6 ; 18.4$ and $22.4 \mathrm{~kg}$ of milk fat.

Regardless of the live weight at the first calving and the level of milk yield, in cows of all groups, lactation proceeds evenly, keeping at a sufficiently high level until the sixth month, and then gradually decreasing.

The level of payment for feed with dairy products in cows of group III with higher dairy production was comparatively low than among peers of groups I and II, which indicates a better payment for feed with milk in highly productive cows. 
The mobile milking machine YDH - 002 provides complete milking of cows, increases the rate of their milk flow, works smoothly and cows get used to it quickly and their use in dairy herds of farms is effective.

\section{References}

1. M. I. Ashirov, B. M. Ashirov, A. A. Yuldashev, Intelligence of Holstein cattle in Uzbekistan, 272 (Navruz Press, Tashkent, 2020)

2. M. I. Ashirov, Improving Swiss cattle in Uzbekistan, 192 (Navruz Press, Tashkent, Uzbekistan, 2020)

3. KH. A. Donaev, M. I. Ashirov, B. M. Ashirov, J. Zootechnics 8, 30-31 (2018)

4. A. A. Yuldashev, M. I. Ashirov, J. Dairy and beef cattle breeding 7, 27-29 (2018)

5. P. Porokhenko, J. Dairy and beef cattle breeding 2, 2-6 (2013)

6. G. M. Djaparidze, V. G. Trufanov, D. V. Novikov, V. V. Djelalov, J. Zootechnics 1, 89 (2013)

7. I. A. Dunin, A. Danquert, A. Kochetkov, J. Dairy and beef cattle breeding 3, 1-5 (2013)

8. N. V. Sivkin, N. I. Strekozov, V. I. Chinarov, J. Dairy industry 6, 62-64 (2001)

9. M. I. Ashirov, KH. A. Donaev, IJSR 7(5), 1596-1598 (2015)

10. A. S. Ibadullaeva, M. I. Ashirov, IJSR 7(5), 1599-1601 (2018)

11. M. I. Ashirov, KH. A. Donaev, IJSR 7(5), 1596-1597 (2018) 